\title{
Influence of Pressure on Germination of Garden Cress, Leaf Mustard, and Radish Seeds at Various Temperatures
}

\author{
Akio Shimizu, Jun Kumakura \\ Department of Environmental Engineering for Symbiosis, Faculty of Engineering, Soka University, Tokyo, Japan. \\ Email: shimizu@soka.ac.jp
}

Received June $16^{\text {th }}, 2011$; revised July $12^{\text {th }}, 2011$; accepted July $25^{\text {th }}, 2011$.

\begin{abstract}
The effects of hydrostatic pressure $(0.1-400 \mathrm{MPa})$ and temperature $\left(4^{\circ} \mathrm{C}, 25^{\circ} \mathrm{C}\right.$, and $\left.35^{\circ} \mathrm{C}\right)$ on the germination of three types of seeds (garden cress, leaf mustard, and radish) were studied. The normal germination rate of the three types of seeds was decreased at high hydrostatic pressure, and germination time tended to be delayed. Pressure and temperature had two types of effects on seed germination. Germination of garden cress and leaf mustard seeds was more resistant to pressure at lower temperature. Conversely, germination of radish seeds was most pressure-sensitive at low temperature, and germination drastically decreased with treatment at $50 \mathrm{MPa}$ and $4^{\circ} \mathrm{C}$. Generally, pressure and temperature effects on protein structure and enzyme activity have been classified into two types, "hillside"-like (pressurization decreases the stable temperature range) and "tongue"-like (stabilizing effect of moderate pressure against heat denaturation). Therefore, the type of temperature-pressure effects on germination of garden cress and leaf mustard seeds is classified as "hillside"-like and that of radish seeds is classified as "tongue"-like, similarly to the generally observed effects on protein denaturation.
\end{abstract}

Keywords: High Hydrostatic Pressure, Germination, Seed, Temperature

\section{Introduction}

Several methods have been proposed for reducing microbial counts [1-8], but none of them completely eliminate pathogens inside seeds. High hydrostatic pressure treatment has been studied as a new approach [9,10-15]. Pressure is an important physical parameter on a par with temperature, but because pressure experiments are difficult to perform, the effectiveness of pressure treatment remains unclear. Nevertheless, high hydrostatic pressure treatment has several merits as compared to other methods: because pressure does not use disinfectants, it leaves no residue on the product $[9,10,14]$, and whereas heat is distributed inhomogeneously and cannot easily reach the central parts of the seed, pressure reaches the inside of seeds homogeneously and instantaneously [16]. On the other hand, application of high hydrostatic pressure to seeds influences germination ability $[9,14,15]$. Therefore, prior to evaluating the effect of pressure on reducing microbial counts, we need to examine the effects of high hydrostatic pressure and temperature on germination percentage and germination time. These parameters have been studied widely for spores [17-22], but rarely for seeds $[9,14,15]$. In particular, to the best of our knowledge, the effect of high hydrostatic pressure on seed germination at low temperature $\left(4^{\circ} \mathrm{C}\right.$, typical refrigerator temperature) has not been investigated. Determination of the effects of pressure and temperature on seed germination would be of great importance not only for collecting fundamental data on the sanitization of seeds but also from the viewpoint of vegetable physiology. In this study, we evaluated the effects of various combinations of hydrostatic pressures $(0.1-400 \mathrm{MPa})$ and temperatures $\left(4^{\circ} \mathrm{C}, 25^{\circ} \mathrm{C}\right.$, and $\left.35^{\circ} \mathrm{C}\right)$ on the germinability and germination time of three types of seeds: garden cress, leaf mustard and radish.

\section{Materials and Methods}

\subsection{Seeds}

Garden cress (place of production: Denmark) and leaf mustard (place of production: Japan) seeds were provided by Takii Seed (Kyoto, Japan), and radish (place of production: USA) seeds were provided by Nakahara 
Seed (Fukuoka, Japan). Seeds were stored at room temperature until high hydrostatic pressure treatment.

\subsection{High Hydrostatic Pressure Treatment}

Approximately 50 seeds were packed in a silicone tube 8 $\mathrm{mm}$ in diameter, $1 \mathrm{~mm}$ thick and $80 \mathrm{~mm}$ long filled with ultrapure water, with both ends of the tube stopped with Teflon rods ( $7 \mathrm{~mm}$ diameter, $15 \mathrm{~mm}$ long). The tube was set in a high-pressure vessel, which was filled with water as the pressure medium and subjected to $50,100,150$, 200, 250, 300 and $400 \mathrm{MPa}$ pressure for $10 \mathrm{~min}$ at $4^{\circ} \mathrm{C}$, $25^{\circ} \mathrm{C}$, and $35^{\circ} \mathrm{C}$ with a hydrostatic pump (Kouatu System, Japan). The compression rate was about $150 \mathrm{MPa} / \mathrm{min}$, and decompression was immediate. Control seeds were not pressurized but were otherwise treated in the same way as pressure-treated seeds. The temperature of the high-pressure vessel was maintained at a preset temperature by circulating water. Experiments were replicate two times.

\subsection{Determination of Germination}

Control and pressure treated seeds were spread on 90$\mathrm{mm}$-diameter filter paper moistened with ultrapure water in a plastic dish and germinated at room temperature for 1 week in the dark. Ultrapure water was sprinkled on the dish every day. The germination percentage (the number of germinated seeds/total number of seeds) was determined by counting the number of germinated seeds.

\section{Results}

All seeds treated with high hydrostatic pressure in this experiment kept their shape better, similarly to untreated seeds; however, the seed coat of some seeds was slightly cracked. Figures 1-3 show the time dependence of gemination percentage for the three types of seeds after high hydrostatic pressure treatment at $4^{\circ} \mathrm{C}, 25^{\circ} \mathrm{C}$, and $35^{\circ} \mathrm{C}$.

Based on these figures, garden cress seeds were the most pressure-resistant at all temperatures studied. As shown in Figure 1, differences in germination percentage of garden cress seeds were observed at shorter germination times up to 2 days; the germination percentage decreased with high hydrostatic pressure treatment. The germination percentage of garden cress reached over $90 \%$ on the seventh day at the three different temperatures, except for seeds treated at $400 \mathrm{MPa}$ and $35^{\circ} \mathrm{C}$. Therefore, the effect of pressure on the germinability of garden cress appeared to be negligible up to $300 \mathrm{MPa}$ at $4^{\circ} \mathrm{C}-35^{\circ} \mathrm{C}$.

As shown in Figure 2, the effects of pressure and temperature on the germinability of leaf mustard seeds showed a similar tendency to that of garden cress, but leaf mustard seeds were more pressure-sensitive than garden cress. A significant decrease in the germinability of leaf mustard was observed at $400 \mathrm{MPa}$, and the germination percentages on the seventh day decreased with increasing temperature, with values at $4^{\circ} \mathrm{C}, 25^{\circ} \mathrm{C}$, and $35^{\circ} \mathrm{C}$ of about $70 \%, 60 \%$, and $50 \%$, respectively.

Similarly to the garden cress and leaf mustard seeds, over $90 \%$ of the untreated control radish seeds germi-

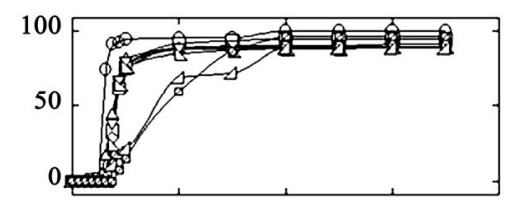

(a)

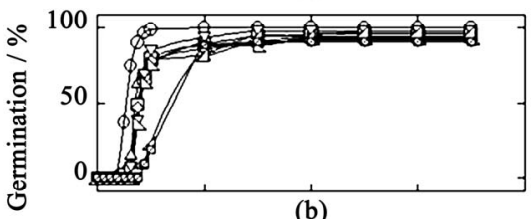

(b)

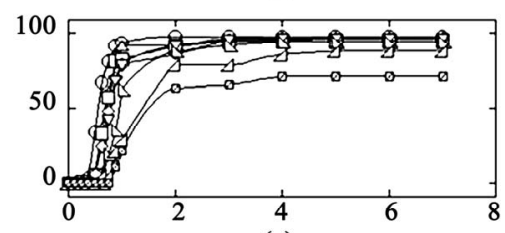

(c)

Germination period / day

O: $0.1 \mathrm{MPa}, \triangle: 50 \mathrm{MPa}, \square: 100 \mathrm{MPa}, \diamond: 150 \mathrm{MPa}, \nabla: 200 \mathrm{MPa}, \triangleright: 250$ $\mathrm{MPa}, \triangle: 300 \mathrm{MPa}, \square: 400 \mathrm{MPa}$.

Figure 1. Effects of high hydrostatic pressure $(0.1$ - 400 MPa) treatment at $4^{\circ} \mathrm{C}(\mathrm{a}), 25^{\circ} \mathrm{C}(\mathrm{b})$, and $35^{\circ} \mathrm{C}$ (c) for $15 \mathrm{~min}$ on the germination of garden cress seeds.

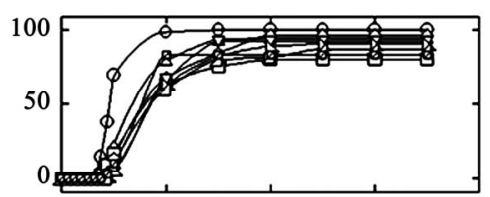

(a)
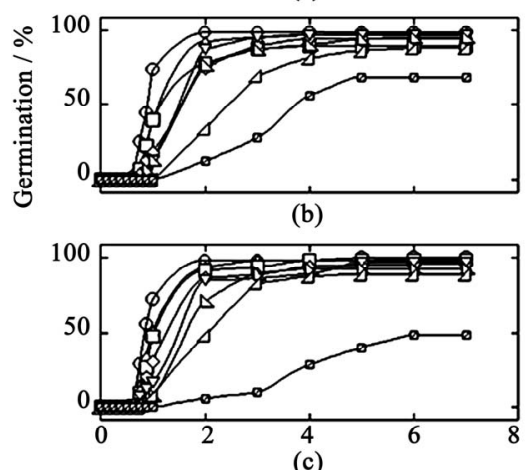

Germination period / day

○: $0.1 \mathrm{MPa}, \triangle: 50 \mathrm{MPa}, \square: 100 \mathrm{MPa}, \diamond: 150 \mathrm{MPa}, \nabla: 200 \mathrm{MPa}, \nabla: 250$ $\mathrm{MPa}, \triangle: 300 \mathrm{MPa}, \square: 400 \mathrm{MPa}$.

Figure 2. Effects of high hydrostatic pressure (0.1 - 400 MPa) treatment at $4^{\circ} \mathrm{C}(\mathrm{a}), 25^{\circ} \mathrm{C}(\mathrm{b})$, and $35^{\circ} \mathrm{C}$ (c) for $15 \mathrm{~min}$ on the germination of leaf mustard seeds. 
nated after 1 day at all three temperatures; however, the germinability of pressure-treated radish seeds (Figure 3) showed significant differences compared to both garden cress and leaf mustard seeds (Figures 1 and 2). Radish seeds were the most pressure-sensitive of the three types of seeds. At $4^{\circ} \mathrm{C}$, the germination percentage decreased to about $25 \%$ at a pressure of only $50 \mathrm{MPa}$, and this low germination percentage was maintained up to $400 \mathrm{MPa}$. However, detailed analysis of the data revealed that the germination percentage recovered slightly at the higher pressures of 350 and $400 \mathrm{MPa}$. The same tendency has been observed for the germination of sesame seeds $20^{\circ} \mathrm{C}$ [14]. Therefore, it is possible that the germination of radish seeds recovers at higher pressures, but future experiments are needed to verify this finding, as the change observed in the present study was relatively small. In contrast, at both $25^{\circ} \mathrm{C}$ and $35^{\circ} \mathrm{C}$, the germination percentage of radish seeds decreased gradually with increasing pressure up to $400 \mathrm{MPa}$.

The time to $50 \%$ germination of pressure-treated garden cress seeds, when treated up to $250 \mathrm{MPa}$, did not significantly differ compared with untreated seeds, but showed an approximately 1-day delay with high pressure treatment at 300 and $400 \mathrm{MPa}$. Leaf mustard seeds showed the same tendency as garden cress seeds, with an approximately 3-day delay at $25^{\circ} \mathrm{C}$ and a 5-day delay when treated at $35^{\circ} \mathrm{C}$ at $400 \mathrm{MPa}$. The $50 \%$ germination time of radish was highly pressure-sensitive compared to both garden cress and leaf mustard seeds, as shown in Figures 1-3; it was delayed with increasing pressure up

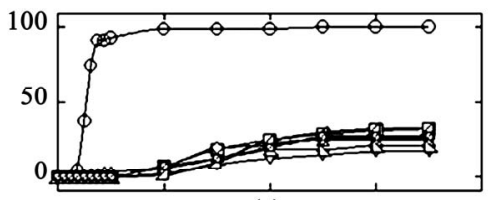

(a)

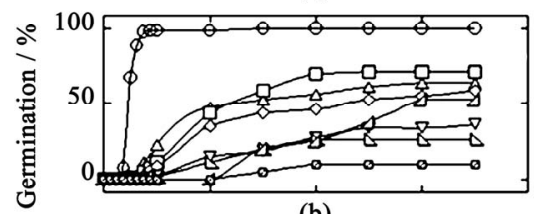

(b)

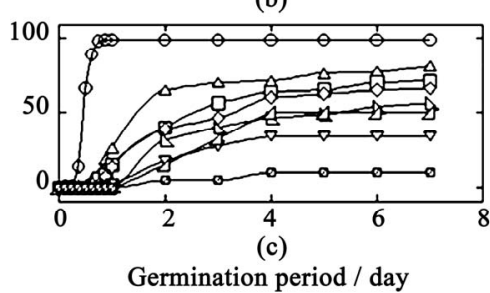

○: $0.1 \mathrm{MPa}, \triangle: 50 \mathrm{MPa}, \square: 100 \mathrm{MPa}, \diamond: 150 \mathrm{MPa}, \nabla: 200 \mathrm{MPa}, \triangleright: 250$ $\mathrm{MPa}, \triangle: 300 \mathrm{MPa}, \square: 400 \mathrm{MPa}$.

Figure 3. Effects of high hydrostatic pressure $(0.1$ - 400 MPa) treatment at $4^{\circ} \mathrm{C}(\mathrm{a}), 25^{\circ} \mathrm{C}(\mathrm{b})$, and $35^{\circ} \mathrm{C}$ (c) for $15 \mathrm{~min}$ on germination of radish seeds. to $200 \mathrm{MPa}$ at $25^{\circ} \mathrm{C}$ and $35^{\circ} \mathrm{C}$. However, when radish seeds were treated with more than $200 \mathrm{MPa}$ at $25^{\circ} \mathrm{C}$ and $35^{\circ} \mathrm{C}$, the germination percentage did not exceed $50 \%$ even after 7 days. Also, germination percentage of radish seeds treated more than $50 \mathrm{MPa}$ at $4^{\circ} \mathrm{C}$ did not exceed $50 \%$ even after 7 days.

\section{Discussion}

In this experiment, we examined the effects of pressure and temperature on the germinability of garden cress, leaf mustard, and radish seeds. The order of germination percentage for the three types of seeds on the seventh day after high hydrostatic pressure treatment at all three temperatures was as follows:

Garden cress $>$ Leaf mustard $>$ Radish.

Our results at $25^{\circ} \mathrm{C}$ showed good agreement with those reported at $20^{\circ} \mathrm{C}$ by Wuytack et al., [21] although there were minor differences in various experimental conditions between our experiments, as follows. 1) We pressurized seeds for $10 \mathrm{~min}$, but Wuytack et al. pressurized for $15 \mathrm{~min}$; 2) we spread seeds on plates holding moistened filter paper, whereas Wuytack et al. spread seeds on $1.2 \%$ agar plates; 3 ) the origin of the seeds was different.

Figure 4 shows the germination percentage on the seventh day (maximum germination percentage) when seeds were treated at various pressures and temperatures. High germination percentages of over $90 \%$ were maintained for garden cress and leaf mustard seeds when

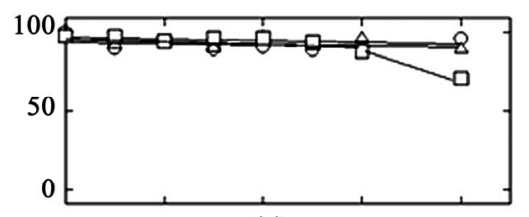

(a)

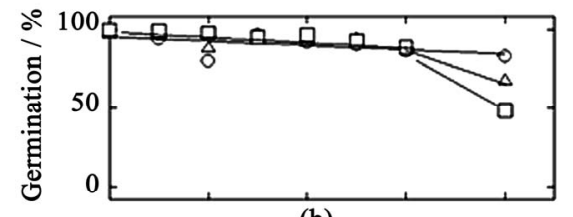

(b)

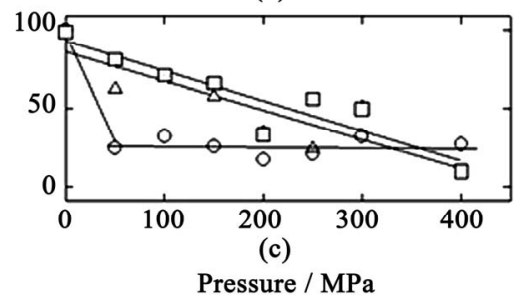

Figure 4. Germination percentage on the seventh day after treatment with high hydrostatic pressure. Each seed was treated with high hydrostatic pressure $(0.1-400 \mathrm{MPa})$ at $4^{\circ} \mathrm{C}$ $(\bigcirc), 25^{\circ} \mathrm{C}(\triangle)$, and $35^{\circ} \mathrm{C}(\square)$ for $15 \mathrm{~min}$. (a) Garden cress; (b) leaf mustard; (c) radish. 
treated up to $300 \mathrm{MPa}$ at $4^{\circ} \mathrm{C}, 25^{\circ} \mathrm{C}$ and $35^{\circ} \mathrm{C}$. The germination percentage decreased linearly by $2 \%-3 \%$ by $100 \mathrm{MPa}$ up to $300 \mathrm{MPa}$. On the other hand, the germination percentage of radish seeds decreased to about $25 \%$ when treated at $50 \mathrm{MPa}$ and $4{ }^{\circ} \mathrm{C}$, and this low germination percentage was maintained at pressures up to 400 MPa. At $25^{\circ} \mathrm{C}$ and $35^{\circ} \mathrm{C}$, the germination percentages of radish seeds decreased linearly with increasing pressure up to $400 \mathrm{MPa}$. Therefore, best-fit lines to the germination percentage at $4^{\circ} \mathrm{C}$ and that at $25^{\circ} \mathrm{C}$ and $35^{\circ} \mathrm{C}$ cross at about 300 and $400 \mathrm{MPa}$ (Figure 4). Therefore, at more than $400 \mathrm{MPa}$, the germination percentage of radish seeds was suppressed greatly and no significant difference due to temperature was observed, at least in the range of $4^{\circ} \mathrm{C}-35^{\circ} \mathrm{C}$.

There have been many investigations of pressure and temperature effects on protein structures and enzyme activities [23-32]. Hawley calculated the Gibbs free energy difference $(\Delta G)$ of the denatured and native state of chymotrypsinogen (his measurements) [25] and ribonuclease A (experiments by Brandts) [26] and obtained a second-order curve for the denaturation conditions $(\Delta \mathrm{G}=$ $0)$ [25]. The experimental data on chymotrypsinogen and ribonuclease A also confirmed that the shape of the phase diagram of the unfolding of these proteins, assuming that the unfolding of the protein is a two-state transition between the native state and denatured state, is elliptical. However, the phase diagrams determined by Hawley for chymotrypsinogen and ribonuclease A differ markedly in shape. Whereas the phase diagram of chymotrypsinogen shows a stabilizing effect of moderate pressure against heat denaturation, pressurization decreases the unfolding temperature of ribonuclease A. Therefore, the phase diagrams of proteins can be classified into two types as a first approximation. Smeller called the phase diagram of chymotrypsinogen "tongue"-like and that of ribonuclease A "hillside"-like [31] Furthermore, the importance of the presence of water is clearly proven by the fact that the data shown in the elliptic diagram can only be observed for protein solutions, and if proteins are in a dry state, they are very pressure stable [31]. Because we pressurized seeds in water, the seeds were more unstable than if pressurized in a dry state. Also, the effects of pressure and temperature on the germination of garden cress and leaf mustard observed in the present experiments were similar to ribonuclease A type protein denaturation, because germination was inhibited at high pressure and high temperature. On the other hand, the effects on the germination of radish seeds were similar to chymotrypsinogen type protein denaturation, because pressure inhibition was remarkable at lower temperatures. From these results over a wide temperature range, the effects of pressure on seed germination can be classified into at least two types, similarly to proteins. This relationship seems reasonable, because it has been suggested that various proteins and/or enzymes contribute to germination [32]. To clarify why each type of seed shows such a tendency, it will be important to clarify what enzymes and proteins are influenced by pressure treatment.

In conclusion, the most important results in the present study observed over wide ranges of temperature $\left(4^{\circ} \mathrm{C}\right.$, $25^{\circ} \mathrm{C}$, and $\left.35^{\circ} \mathrm{C}\right)$ and pressure $(0.1-400 \mathrm{MPa})$ was that the effects of pressure and temperature on germinability could be classified into two types. One type, represented by garden cress and leaf mustard seeds, showed more pressure-resistant germination at lower temperatures. The other type, represented by radish, showed the highest pressure sensitivity at low temperature $\left(4^{\circ} \mathrm{C}\right)$ and greatly decreased germination with treatment at lower pressure $(50 \mathrm{MPa})$.

\section{REFERENCES}

[1] A. Weiss and M. S. Hammes, "Thermal Seed Treatment to Improve the Food Safety Status of Sprouts," Journal of Applied Botany, Vol. 77, No. 5-6, 2003, pp. 152-155.

[2] C. B. Jaquette, L. R. Beuchat, B. E. Mahon, "Efficacy of Chlorine and Heat Treatment in Killing Salmonella Stanley Inoculated onto Alfalfa Seeds and Growth and Survival of the Pathogen during Sprouting and Storage," Applied Environmental Microbiology, Vol. 62, No. 7, 1996, pp. 2212-2215.

[3] D. W. Thayer, K. T. Rajkowski, G. Boyd, P. H. Cooke and D. S. Soroka, "Inactivation of Escherichia coli O157:H7 and Salmonella by Gamma Irradiation of Alfalfa Seed Intended for Production of Food Sprouts," Journal of Food Protection, Vol. 66, No. 2, 2003, pp. 175-181.

[4] L. R. Beuchat, T. E. Ward and C. A. Pettigrew, "Comparison of Chlorine and a Prototype Produce Wash Product for Effectiveness in Killing Salmonella and Escherichia coli O157:H7 on Alfalfa Seeds," Journal of Food Protection, Vol. 64, No. 2, 2001, pp. 152-154.

[5] D. W. Thayer, K. Rajkowsk, G. Boyd, P. Cooke and D. S. Soroka, "Inactivation of Escherichia coli O157:H7 and Salmonella by Gamma Irradiation of Alfalfa Seed Intended for Production of Food Sprouts," Journal of Food Protection, Vol. 66, No. 2, pp. 175-181.

[6] K. L. Winthrop, M. S. Palumbo, J. A. Farrar, J. C. MohleBoetani, S. Abbott, M. E. Beatty, G. Inami and S. B. Werner, "Alfalfa sprouts and Salmonella Kottbus infection: A Multistate Outbreak Following Inadequate Seed Disinfection with Heat and Chlorine," Journal of Food Protection, Vol. 66, No. 1, 2003, pp. 13-17.

[7] V. Piernas and J. P. Guiraud, "Microbial Hazards Related to Rice Sprouting," International Journal of Food Science and Technology, Vol. 32, No. 1, 1997, pp. 33-39.

[8] R. R. Sharma, A. Demirci, L. R. Beuchat and W. F. Fett, "Inactivation of Escherichia coli O157:H7 on Inoculated Alfalfa Seeds with Ozonated Water and Heat Treatment," 
Journal of Food Protection, Vol. 65, No. 3, 2002, pp. 447-451.

[9] E. Peñas, R. Gómez, J. Frías and C. Vidal-Valverde, “Application of High-Pressure Treatment on Alfalfa (Medicago sativa) and Mung Bean (Vigna radiata) Seeds to Enhance the Microbiological Safety of Their Sprouts," Food Control, Vol. 19, No. 7, 2008, pp. 698-705. doi:10.1016/j.foodcont.2007.07.010

[10] G. Préstamo, M. Lesmes, L. Otero and G. Arroyo, "Soybean Vegetable Protein (Tofu) Preserved with High Pressure," Journal of Agricultural and Food Chemistry, Vol. 48, No. 7, 2000, pp. 2943-2947. doi:10.1021/jf991251y

[11] H. Neetoo, M. Ye and H. Chen, "Potential Application of High Hydrostatic Pressure to Eliminate Escherichia coli O157:H7 on Alfalfa Sprouted Seeds," International Journal of Food Microbiology, Vol. 128, No. 2, 2008, pp. 348-353. doi:10.1016/j.ijfoodmicro.2008.09.011

[12] H. Neetoo, T. Pizzolato and H. Chen, "Elimination of Escherichia coli O157:H7 from Alfalfa Seeds through a Combination of High Hydrostatic Pressure and Mild Heat," Applied and Environmental Microbiology, Vol. 75, No. 7, 2009, pp. 1901-1907. doi:10.1128/AEM.02531-08

[13] H. Neetoo and H. Chen, "Inactivation of Salmonella and Escherichia coli O157:H7 on Artificially Contaminated Alfalfa Seeds Using High Hydrostatic Pressure," Food Microbiology, Vol. 27, No. 3, 2010, pp. 332-338. doi:10.1016/j.fm.2009.11.003

[14] E. Y. Wuytack, A. M. Diels, K. Meersseman and C. W. Michiels, "Decontamination of Seeds for Seed Sprout Production by High Hydrostatic Pressure," The Journal of Food Protection, Vol. 66, No. 6, 2003, pp. 918-923.

[15] E. Peñas, R. Gómez, J. Frías and C. Vidal-Valverde, "Effects of Combined Treatments of High Pressure, Temperature and Antimicrobial Products on Germination of Mung Bean Seeds and Antimicrobial Quality of Sprouts," Food Control, Vol. 21, No. 1, 2010, pp. 82-88. doi:10.1016/j.foodcont.2009.04.008

[16] National Advisory Committee on Microbial Criteria for Foods, Food and Drug Administration, "Microbiological Safety Evaluations and Recommendations on Sprouted Seeds. National Advisory Committee on Microbiological Criteria for Foods," International Journal Food Micrbiology, Vol. 52, No. 3, 1999, pp. 123-153.

[17] Y. Shigeta Y. Aoyama, T. Okazaki, Y. Hagura and K. Suzuki, "Hydrostatic Pressure-Induced Germination and Inactivation of Bacillus spores in the Presence or Absence of Nutrients," Food Science and Technology Research, Vol. 13, No. 3, 2007, pp. 193-199. doi:10.3136/fstr.13.193

[18] L. Clinquanta, D. Albanese, G. Cuccurullo and M. Di Mtteo, "Effect on Orange Juice of Batch Pasteurization in an Improved Pilot-Scale Microwave Oven," Journal of Food Science, Vol. 75, No. 1, 2010, pp. E46-E50. doi:10.1111/j.1750-3841.2009.01412.x

[19] G. W. Gould and A. J. H. Sale, "Initiation of Germination of Bacterial Spores by Hydrostatic Pressure," Journal of General Microbiology, Vol. 60, No. 3, 1970, pp. 335-346.

[20] E. Y. Wuytack, S. Boven and C. W. Michiels, "Compara- tive Study of Pressure-Induced Germination of Bacillus subtilis Spores at Low and High Pressures," Applied and Environmental Microbiology, Vol. 64, No. 9, 1998, pp. 3220-3224.

[21] E. Y. Wuytack, J. Soons, F. Poschet and C. W. Michiels, "Comparative Study of Pressure- and Nutrient-Induced Germination of Bacillus subtilis Spores," Applied and Environmental Microbiology, Vol. 66, No. 1, 2000, pp. 257-261. doi:10.1128/AEM.66.1.257-261.2000

[22] H. Nguyen Thi Minh, P. Dantigny, J. M. Perrier-Cornet and P. Gervais, "Germination and Inactivation of Bacillus subtilis Spores Induced by Moderate Hydrostatic Pressure," Biotechnology and Bioengineering, Vol. 107, No. 5, 2010, pp. 876-883. doi:10.1002/bit.22849

[23] Y. Taniguchi and K. Suzuki, "Studies of Polymer Effects under Pressure. Part 7. Pressure Inactivation of AlphaChymotrypsin," The Journal of Physical Chemistry. Vol. 87, No. 25, 1983, pp. 5185-5193. doi: $10.1021 / \mathrm{j} 150643 \mathrm{a} 025$

[24] J. Wiedersich, S. Köhler, A. Skerra and J. Friedrich, "Temperature and Pressure Dependence of Protein Stability: The Engineered Fluorescein-Binding Lipocalin FluA Shows an Elliptic Phase Diagram," Proceedings of the National Academy of Sciences of the USA, Vol. 105, No. 15, 2008, pp. 5756-5761. doi:10.1073/pnas.0710409105

[25] S. A. Hawley, "Reversible Pressure-Temperature Denaturation of Chymotrypsinogen," Biochemistry, Vol. 10, No. 13, 1971, pp. 2436-2442.

[26] J. F. Brandts, R. J. Oliveira and C. Westort, "Thermodynamics of Protein Denaturation. Effect of Pressure on the Denaturation on Ribonuclease A," Biochemistry, Vol. 9, No. 4, 1970, pp. 1038-1047.

[27] G. Panick, G. J. A. Vidugiris, R. Malessa, G. Rapp, R. Winter and C. A. Royer, "Exploring the Temperature-Pressure Phase Diagram of Staphylococcal Nuclease," Biochemistry, Vol. 38, No. 13, 1999, pp. 4157-4164.

[28] E. Morild, "Pressure Variation of Enzymatic Reaction Rates: Yeast and Liver Alcohol Dehydrogenase," Biophysical Chemistry, Vol. 6, No. 3, 1977, pp. 351-362. doi:10.1016/0301-4622(77)85016-3

[29] S. Dallet, M. D. Legoy, "Hydrostatic Pressure Induces Conformational and Catalytic Changes on Two Alcohol Dehydrogenases but No Oligomeric Dissociation," Biochimica et Biophysica Acta, Vol. 1294, No. 1, 1996, pp. 15-24.

[30] Y. K. Cho and D. B. Northrop, "Effects of Pressure on the Kinetics of Capture by Yeast Alcohol Dehydrogenase," Biochemistry, Vol. 38, No. 23, 1999, pp. 7470- 7475.

[31] L. Smeller, "Pressure-Temperature Phase Diagram of Biomolecules," Biochimica et Biophysica Acta, Vol. 1595, No. 1, 2002, pp. 11-29. doi:10.1016/S0167-4838(01)00332-6

[32] U. Piskurewicz, V. Turečková, E. Lacombe and L. Lopez-Molina, "Far-Red Light Inhibits Germination through DELLA-Dependent Stimulation of ABA Synthesis and ABI3 Activity," The EMBO Journal, Vol. 28, No. 15, 2009, pp. 2259-2271. doi:10.1038/emboj.2009.170 